\title{
Wysheidskriteria vir die klassifikasie van psalms as wysheidspsalms
}

\author{
J Burger \\ Universiteit van Suid-Afrika
}

\begin{abstract}
Criteria for identyfying wisdom psalms

This article concerns itself with the identification of wisdom poems amongst the psalms in the Old Testament. Certain criteria for identifying wisdom psalms have already been determined through previous research on the subject. The validity of these criteria is subsequently evaluated in the light of the generally accepted wisdom books namely Job, Proverbs and Ecclesiastes. This attempt generated an independent set of criteria (formal and pertaining contents) proposed for isolating wisdom psalms.
\end{abstract}

\section{INLEIDEND}

Die doel van hierdie artikel is om 'n stel kriteria op te stel wat gebruik kan word om die wysheidspsalms in die psalmbundel te bepaal. Aangesien die wysheidsliteratuur in die Ou Testament meestal poësie is, sou 'n mens verwag dat stilistiese, of formele aspekte belangrik sou wees in hierdie literatuur. Daarom behoort nie slegs inhoudelike aspekte, waaroor dit per slot van rekening eintlik gaan, in die bepaling van die wysheidspsalms gebruik te word nie, maar ook formele aspekte. Formele en inhoudelike kriteria (vgl Crenshaw 1981:19), kenmerkend van die algemeen erkende wysheidsboeke Job, Spreuke en Prediker, moet aangelê word ten opsigte van die uitken van wysheidspsalms. Langs hierdie weg word dan tot 'n eie stel kriteria (inhoudelik en formeel) gekom met behulp waarvan wysheidspsalms in die psalmbundel geïsoleer kan word. Terwyl hierdie kriteria geëvalueer word, word terselfdertyd 'n oorsig oor die navorsing in verband met die wysheidspsalms gegee.

Ten einde die inhoudelike en formele kriteria wat op dié manier vasgestel is, nie na willekeur te gebruik nie, moet daar 'n bepaalde dissipline op hulle aanwending toegepas word: Hiervolgens word uitgegaan van die standpunt dat slegs psalms 
wat beduidende kenmerke van sowel die formele as inhoudelike kategorieë vertoon, wysheidspsalms is. Die oorkoepelende beginsel vir die isolering van wysheidspsalms is dus die samevloeiing van tersaaklike getuienis. Die psalms wat ooreenkomstig dié werkwyse as wysheidspsalms gekwalifiseer kan word, is Psalm 1, 32, 34, 37, 49, 112 , 127 en 128.

\section{2. 'N OORSIG VAN DIE WYSHEIDSPSALMNAVORSING}

Daar is al heelwat navorsing oor die wysheidspsalms gedoen en uiteraard is daar reeds kriteria deur navorsers bepaal waarvolgens die wysheidspsalms herken kan word. Vervolgens kyk ons eers na die kriteria waarvolgens 'n mens wysheidspsalms kan uitken soos opgestel deur 'n aantal navorsers op dié gebied. Daarna word dié kriteria geëvalueer ten einde tot 'n eie stel kriteria te kom.

\subsection{Hermann Gunkel}

Gunkel kan met reg beskou word as die grondlegger van die moderne psalmnavorsing, soos blyk uit sy omvattende psalmstudie van 1933 wat na sy dood deur Joachim Begrich in 1975 voltooi is: Einleitung in die Psalmen: Die Gattungen der religiösen Lyrik Israels. In hierdie inleiding gee Gunkel (1975:381-397) ruim aandag aan die sogenaamde Weisheitsdichtung in die psalmbundel, alhoewel hy huiwerig voorkom om dié genre op dieselfde vlak met die ander Gattungen soos die himne en die individuele klaaglied te beskou. Die Weisheitsdichtung in die psalmbundel bestaan volgens hom uit Psalm 1, 37, 49, 73, 91, 112 en 128.

Gunkel (1975:389-392) vergelyk die psalmbundel met die wysheidsgeskrifte in die Ou Testament en die wysheidsliteratuur van die Nabye Ooste op grond van - en dit is veral hier van belang - vormkritiese (formele) en tematiese (inhoudelike) kenmerke. Hierdie kenmerke gebruik hy om te bepaal watter psalms wysheidspsalms is. Die formele wysheidskenmerke wat hy onderskei, is: Vermaning gerig a an 'seuns'; wysheidswoordeskat ('wysheid'; 'lering'; 'raaisel'; 'spreuk'); die vergelyking; die retoriese vraag; die getallespreuk en die seën-formule. Sy inhoudelike wysheidskenmerke is die vrees vir Jahwe en die vergelding.

Alhoewel Gunkel nie altyd presies is oor hierdie wysheidskenmerke nie en hy dit ook nie in soveel woorde as 'kriteria' vir die uitwys van wysheidspsalms tipeer nie, bied sy studie 'n stewige basis waarop in die latere wysheidspsalmnavorsing gebou is. 


\subsection{Sigmund Mowinckel}

Vir die Oslose Ou-Testamentikus Sigmund Mowinckel (1960:205), is die psalms, op slegs 'n paar uitsonderings na, gedig vir gebruik in die kultus. Die paar psalms wat nie by hierdie kultiese Sitz im Leben inpas nie, spruit volgens Mowinckel uit 'n private agtergrond. Hy noem dit didaktiese 'psalms' (sy aanhalingstekens), wat 'n aanduiding is van sy verleentheid met hierdie psalms omdat dit nie kulties is nie, terwyl 'n psalm volgens sy denkskema by implikasie kulties is (Mowinckel 19501951:205). Hy praat van 'geleerde psalmografie' en skram weg van die term wysheidspsalm.

Die kriteria waarvolgens Mowinckel hierdie nie-kultiese psalms herken, bepaal hy as formeel en inhoudelik sonder om in besonderhede daarop in te gaan. Die didaktiese psalms is volgens hom deur die styl (vorm) van die wysheidspoësie soos Spreuke beïnvloed (Mowinckel 1950-1951:224), hoewel hy nie die spesifieke stilistiese aspekte noem nie. So vaag as wat Mowinckel oor die formele kriteria is, net so vaag is hy oor die inhoudelike. Alle psalms wat nie tot die kultus herlei kan word nie en didaktiese aspekte bevat, is wysheidspsalms - voorwaar 'n baie vae inhoudelike tipering. Die naaste wat hy aan 'n meer presiese omskrywing van die inhoud kom, is wanneer hy die didaktiese psalms as 'n 'probleempoësie' omskryf. Inhoudelik word daarin gehandel oor die basiese religieuse probleem van die Jode, naamlik die regverdigheid van God wat betref die verdeling van geluk en lyding (Mowinckel 1950-1951:224). Volgens Mowinckel (1962:111) is die didaktiese psalms in die psalmbundel Psalm 1, 19b, 34, 37, 49, 73, 78, 105, 106, 111, 112 en 127.

\subsection{Gerhard von Rad}

Soos vir Mowinckel, lê die probleem van die psalmeksegese vir Von Rad (1970:7071) nie by die kultiese psalms nie, maar by die nie-kultiese psalms. Volgens Von Rad beskik ons nie oor vaste kriteria om hierdie nie-kultiese psalms te bepaal nie. Die uitwys van hierdie psalms berus volgens hom op 'n 'algemene indruk' van 'n didaktiese kwaliteit en van 'n oorwegend teologiese refleksie. Hierdie gedigte behoort tot verskeie Gattungen wat deur die wysheidsleraars gebruik is as kanaal om hulle insigte en probleme uiteen te sit en is volgens hom nie 'n eie Gattung nie. Von Rad noem hierdie gedigte Gebete in die mond van die wyses. Dit het 'n dubbele karakter, naamlik dié van 'n gebed tot God en onderig aan leerlinge (Schuldichtung) met die gebed as die dominante karaktertrek.

\subsection{James L Crenshaw}

Crenshaw is skepties oor die pogings van navorsers om wysheidsinvloed in literatuur buite die boeke Job, Spreuke en Prediker te vind. In sy inleiding op die Ou- 
Testamentiese wysheid (Crenshaw 1981:39-41,184) sowel as in twee van sy artikels (vgl Crenshaw 1967:49; 1969:142) poog hy om hierdie neiging te stuit. Hy maak van ongegronde uitsprake gebruik wanneer hy 'n stelling soos die volgende maak: 'This trend has caught on so widely that the entire Hebrew canon is in danger of being swallowed' (Crenshaw 1981:41). Hy sien hierdie pogings as 'n futiele 'widening of the net' (Crenshaw 1981:41; vgl ook bl 185). Hy kyk skeef op (soos hy dit uitdruk) na sekere formele en tematiese oorwegings om wysheid in ander literatuur aan te dui. Ten spyte hiervan ontken hy nie dat die wyses van Israel, soos wat uit die psalmbundel blyk, aan die kultiese lewe deelgeneem het en dit ook direk beïnvloed het nie (Crenshaw 1981:185). Crenshaw se afwysing van formele en inhoudelike kriteria oortuig nie. Indien dit uit die lees van 'n bepaalde psalm blyk dat daar wysheidsinvloed is (soos Crenshaw toegee), hoe kan 'n mens ánders as met behulp van formele en inhoudelike kriteria, bepaal of die 'wysheid' in so 'n psalm mér is as blote beïnvloeding? Dit is interessant om te sien dat Crenshaw twaalf jaar tevore wel van mening was dat sulke kriteria ' $n$ rol kan speel: In 1969 skryf hy dat stilistiese (formele) of ideologiese (inhoudelike) aspekte wat in die wysheidsliteratuur te vinde is, wel van nut is in die bepaling van wysheidsinvloed in ander literatuur (Crenshaw 1969:132).

Alhoewel hy blykbaar daarvan wegskram om die term 'wysheidspsalms' te gebruik, ontken Crenshaw nie die invloed van die wysheid in die psalms nie. Naas enkele verse in sommige psalms wat uit wysheidsirkels afkomstig is, soos Psalm 32:8-9, 94:8-11 en 62:8-12 (Crenshaw 1981:184), noem hy twee groepe psalms wat die affiniteit tussen die psalms en die wysheid aantoon, naamlik 'discussion literature' (Ps 37, 39, 49, 73) wat handel oor die regverdigheid van God in die lig van die oënskynlike voorspoed van die goddeloses, en 'torah meditation' (Ps 1) wat handel oor die voorspoed van diegene wat die wet oordink (Crenshaw 1981:181183). Crenshaw is egter vaag in die benoeming van psalms onder dié twee groepe. 'n Mens wonder wat die invloed van Von Rad op hom was, aangesien Von Rad van basies dieselfde twee groepe in die psalms praat, naamlik probleem- of refleksiegedigte en Torapsalms.

\subsection{R B Y Scott}

Scott (1971:193) wys op die onduidelikheid wat onder navorsers bestaan oor watter psalms wysheidspsalms is. Hy wys egter ook daarop dat daar oor die wysheidskwaliteit van Psalm 1, 37, 49 en 112 redelik algemene ooreenstemming onder navorsers bestaan. Hy analiseer hierdie vier psalms en bepaal daaruit wysheidskriteria wat hy as sleutel gebruik om die res van die psalmbundel te ontsluit vir wysheidspsalms (Scott 1971:193). Hierdie werkwyse van Scott ten einde die kriteria te 
bepaal, is egter te bevraagteken want hy aanvaar bloot op grond van die werk van ander navorsers - wie se kriteria verskil - dat hierdie vier psalms wysheidspsalms is. Hy kon by 'n totaal ander konklusie uitgekom het as hy die kriteria van verskillende navorsers op dié gebied geëvalueer het.

Nadat hy dié vier psalms ontleed het, bepaal hy die volgende formele en tematiese (inhoudelike) kriteria (Scott 1971:197-198). Die formele kriteria is: Psalms gerig aan mense, nie aan Jahwe nie; wysheidswoordeskat; spreuke; voorskrifte; vergelykings; illustrasies uit die natuur; retoriese vrae; die onderwyser se oproep vir aandag en die alfabetiese struktuur. Inhoudelik bepaal hy die volgende kriteria: Die goddeloses teenoor die regverdiges; die vergeldingsleer; die studie van die Tora; oproep tot vertroue in Jahwe en poging tot die verstaan van geloofsprobleme.

Op grond van hierdie kriteria kan die volgende twaalf psalms volgens hom as wysheidspsalms geklassifiseer word: Psalm 1, 19b, 32, 34, 37, 49, 78, 112, 119, 127, 128 , en 133 (1971:201).

\subsection{J Kenneth Kuntz}

Kuntz maak van retoriese (formele) en tematiese (inhoudelike) wysheidskriteria gebruik om die wysheidspsalms uit te wys. In stygende orde van belangrikheid noem hy die volgende sewe retoriese kriteria (Kuntz 1977:224-225): Die 'beter'-spreuk; die getallespreuk; die vermaning gerig aan 'seuns'; die retoriese vraag; die vergelyking; die vermaningspreuk (Mahnspruch) en die seën-formule. Daar is volgens hom vier tematiese kriteria naamlik: Die vrees vir Jahwe en eerbied vir die Tora; die regverdiges teenoor die goddeloses; die vergelding en raad in verband met alledaagse gedrag.

Volgens hierdie formele en inhoudelike kriteria klassifiseer Kuntz (1974:210; 1977:225) die volgende psalms as wysheidspsalms: Psalm 1, 32, 34, 37, 49, 112, 127 , 128 en 133.

\subsection{R N Whybray}

Volgens Whybray was daar in Israel 'n intellektuele tradisie wat die produk was van 'n opgevoede klas (nie 'n skool of instelling nie). Hierdie wysheidstradisie is op informele wyse oorgelewer en het wyer uitgekring as net die boeke Job, Spreuke en Prediker (Whybray 1974:70-71). Hy wys ook op die groot verwarring onder geleerdes om wysheidstradisies in die res van die Ou Testament te herken juis omdat hulle kriteria grootliks verskil (Whybray 1974:2). Vir Whybray is formele asook inhoudelike kriteria belangrik om wysheid in die Ou Testament te bepaal. Ongelukkig tipeer hy nie die formele en inhoudelike kriteria nie. Volgens hom kan die invloed van die intellektuele tradisie in die volgende psalms gesien word (hy tipeer die 
psalms nie as wysheidspsalms nie): Psalm 1, 19:8-15, 37, 49, 51, 73, 90, 92, 94, 104, 107, 111 en 119 (Whybray 1974:154).

\subsection{Roland E Murphy}

Nadat Murphy gewys het op die meningsverskil onder navorsers oor watter psalms tot die Gattung van wysheidspsalms behoort, sê hy dat dié situasie bestaan omdat daar 'n gebrek is aan aanvaarbare kriteria vir die presiese bepaling van hierdie tipe psalm. Hy is van mening dat dié kriteria inhoudelik en formeel moet wees en dat die voorkoms van hierdie twee kriteria saam die Gattung kan bepaal (Murphy 1962: 159-160). Die stilistiese (formele) kriteria is die volgende: 'seën'-formules; getallespreuke; 'beter'-spreuke; die aanspreek van 'n seun deur 'n onderwyser; die alfabetiese struktuur; vergelykings en vermanings. Die inhoudelike kriteria sien soos volg daaruit: Die kontras tussen die regverdiges en die goddeloses; die twee weë; die vergeldingsleer; praktiese raad in verband met gedrag en die vrees vir Jahwe.

Op grond van hierdie kriteria behoort die volgende sewe psalms volgens Murphy (1962:161) tot die Gattung wysheidspsalms: Psalm 1, 32, 34, 37, 49, 112 en 128.

\section{DIE BEPALING VAN DIE WYSHEIDSKRITERIA}

\section{1 'n Kompendium van wysheidskriteria}

Uit die geselekteerde navorsingsoorsig hierbo blyk dat die wysheidskriteria normaalweg formeel sowel as inhoudelik is. Hieroor is al die bogenoemde navorsers met die uitsondering van slegs Von Rad en Crenshaw dit eens. Alhoewel Von Rad meen dat ons nie oor kriteria hiervan beskik nie en Crenshaw skepties daarteenoor staan, maak hulle tog van inhoud gebruik om hulle sogenaamde Torapsalms en probleem- of refleksiegedigte (Von Rad) asook psalms van Tora-meditasie en diskussieliteratuur (Crenshaw) te bepaal as psalms met wysheidsinvloed.

Gunkel, Scott, Kuntz en Murphy gaan in besonderhede in op die formele en inhoudelike kriteria, terwyl Mowinckel en Whybray slegs noem dat die kriteria formeel en inhoudelik moet wees. Met behulp van die wysheidskriteria van Gunkel, Scott, Kuntz en Murphy kan die volgende kompendium saamgestel word.

\section{Formele kriteria:}

- Die 'seën'-formules (Gunkel, Kuntz, Murphy);

- die 'beter'-spreuk (Kuntz, Murphy); 
- die alfabetiese struktuur (Gunkel, Scott, Murphy);

- die getallespreuk (Gunkel, Kuntz, Murphy);

- die 'seun'-formule (Gunkel, Scott, Kuntz, Murphy);

- die retoriese vraag (Gunkel, Scott, Kuntz);

- die vermaning (Mahnspruch) (Scott, Kuntz, Murphy);

- die vergelyking (Gunkel, Scott, Kuntz, Murphy);

- wysheidswoordeskat (Gunkel, Scott);

- die spreuk (Scott).

Inhoudelike kriteria:

- die regverdige teenoor die goddelose (Scott, Kuntz, Murphy);

- die vrees vir Jahwe (Gunkel, Scott, Kuntz, Murphy - Scott noem dit vertroue in Jahwe);

- $\quad$ eerbied vir die Tora (Scott, Kuntz, Murphy);

- die vergeldingsleer (Gunkel, Scott, Kuntz, Murphy);

- $\quad$ praktiese raad in verband met die alledaagse gedrag (Kuntz, Murphy);

- die twee weë (Murphy).

Ten einde 'n stel formele en inhoudelike wysheidskriteria saam te stel wat as sleutel kan dien om die wysheidspsalms mee te bepaal, word bogenoemde kriteria aan die hand van die wysheidsboeke Job, Spreuke en Prediker gemeet. Indien hierdie aspekte, of sommiges daarvan, inderdaad tipies van die wysheid is, sal dit ook kenmerkend van hierdie drie boeke moet wees.

3.2 'n Evaluering van die wysheidskriteria aan die hand van die wysheidsboeke Job, Spreuke en Prediker

\subsubsection{Formele kriteria}

\subsubsection{Die 'seën'-formule}

Die term אשרי (heil, geluk) kom vyf en veertig keer in die Ou Testament voor, waarvan ses en twintig keer in die psalmbundel en agt keer in die Spreukeboek, asook een keer in Prediker. In die res van die Ou Testament kom dit 'n verdere nege keer voor. Dit is onduidelik of ' אשר 'n wens of bloot 'n verklaring is. Volgens Brockelmann (1966 [1913]:25-27) mag dit'n wens uitdruk, maar hy toon ook aan dat daar 'n neiging in die meeste Semitiese tale is om 'n nominale sin wat 'n wens uitdruk in die vorm van 'n gewone verklarende sin te konstrueer. Dit is daarom moeilik om te bepaal of אשר 'n wens of 'n stelling is. Ten spyte van hierdie onseker- 


\section{Wyshcidspsalms}

heid, kan die term vertaal word as 'gelukkig' of 'geseënd'. 'Geseënd is die mens vir wie God teregwys en moenie die tug van die Almagtige verwerp nie' (Job 5:17).

Alhoewel die 'seën'-formule verreweg die meeste van al die kanonieke boeke in die psalmbundel voorkom, is dit nietemin goed bekend in die wysheidsliteratuur. Omdat dit meer met die psalmbundel as met die wysheidsboeke (Job, Spreuke en Prediker) geassosieer word, word die argument ten gunste van die term as wysheidskriterium verswak. Saam met ander kriteria kan dit egter steeds as 'n nuttige wysheidskriterium gebruik word.

\subsubsection{Die 'beter'-spreuk}

Die 'beter'-spreuk is 'n vergelyking tussen twee sake waarin een saak voorkeur geniet bo 'n ander: Wysheid is beter as oorlogwapens, maar een oortreding bederf baie goeie dinge (Pred 9:18). Alhoewel dit in die boek Job ontbreek, kom dit talle kere in Spreuke en Prediker voor, waaruit onteenseglik blyk dat dit kenmerkend van die wysheid is. Dit kom ook ses keer in die psalmbundel voor (Ps 37:16; 63:4; 84:11; $118: 8,9 ; 119: 72)$, wat die wysheidsinvloed in die psalmbundel bevestig.

\subsubsection{Die alfabetiese struktuur}

In gedigte met 'n alfabetiese struktuur volg die beginletters van elke vers of strofe die volgorde van die Hebreeuse alfabet. 'n Moontlike verklaring vir die gebruik van die alfabetiese struktuur soos wat dit in die Ou Testament voorkom, is dat die wysheidsleraars dit as geheuehulp vir hulle leerlinge in die wysheidskole gebruik het. Hierdie standpunt word ondersteun uit die feit dat Albright (1950:11-20) aangetoon het dat die alfabetiese orde as geheuehulp vroeg reeds in Ugarit bekend was. Die didaktiese aard van die wysheid mak die gebruik van die alfabet as 'n onderrighulp vir leerlinge ook baie waarskynlik.

Die alfabetiese of akrostiese struktuur ontbreek in Prediker en Job maar kom wel in die laaste hoofstuk van Spreuke voor (31:10-31) waar elk van die twee en twintig stiges met 'n nuwe letter begin. Hierdie struktuur kom ook buite die tradisionele wysheidsliteratuur voor, naamlik in Psalm 9/10, 25, 34, 37, 111, 112, 119 en 145, asook in Klaagliedere 1-4 en Nahum 1:2-8. Die vraag kan tereg gevra word of die alfabetiese struktuur 'n kenmerk van die wysheid is wat as kriterium in die bepaling van die wysheidspsalms gebruik kan word. In die lig van die feit dat hierdie struktuur meer buite die erkende wysheid as daarbinne voorkom, maak dit 'n gewigtige vraag. Die alfabetiese struktuur op sigself kan nie as 'n wysheidskriterium gebruik word nie. Dit kan egter wel as kriterium in samehang met ander kriteria gebruik word. Die sterkste argument ten gunste van die alfabetiese struktuur as wysheidskriterium is dat dit op logiese gronde as geheuehulp by die didak- 
tiese karakter van die Israelitiese wysheid inpas.

\subsubsection{Die getallespreuk}

In 'n getallespreuk word 'n getal genoem en direk daarna die getal net hoër wat dan gevolg word deur' $n$ lys gelyk aan die laaste getal:

Kyk, drie dinge word nooit versadig nie en vier sê nooit 'genoeg' nie:

Die onderwêreld, 'n geslote moederskoot, die aarde wat nie genoeg water kry nie en vuur wat nooit 'genoeg' sê nie.

(Spr 30:15b-16)

Die getallespreuk kom ook voor in Spreuke 30:18-19; 21-23 en 29-31 asook een keer in die psalmbundel (Ps 62:12-13). Spreuke soortgelyk aan die getallespreuk waarin die lys sake soms uitgelaat word, kom voor in Amos 1:3, 6, 9, 11, 13; 2:1, 4, 6 in Job 33:14-15 en in Psalm 27:4.

Die oorsprong van die getallespreuk is waarskynlik Kanaänities, soos blyk uit die Ugaritiese teks 51 iii 17-21 (vgl Gordon 1965:170; Pritchard 1969:132). Buite die Ou Testament kom dit ook nog in die Agikarspreuke voor (vgl Pritchard 1969: 428) asook in Ben Sira 25:7-11; 26:5-6, 28 en 50:25-26 (vgl Wolff 1964:27-30).

Soos in die geval met die alfabetiese struktuur, kon die getallespreuk ook as geheuehulp in die didaktiese wysheidskonteks gebruik word - in albei gevalle is daar 'n lys sake wat geleer moes word. Die getallespreuk het, kenmerkend van 'n onderrigsituasie, 'n raaiselkarakter: Wie sal eerste kan raai wat die sake is wat genoem gaan word? Hierdie aspek van die getallespreuk is 'n argument ten gunste van die didaktiese en dus wysheidskarakter daarvan.

Dit lyk dus dat die wysheidsleraar, soos veral blyk uit Spreuke, 'n liefde vir die getallespreuke gehad het. As gevolg hiervan en op grond van die feit dat dit min buite die wysheid voorkom, kan die getallespreuk in hierdie studie as 'n wysheidskriterium gebruik word.

\subsubsection{Die 'seun'-formule}

Die didaktiese karakter van die wysheidsliteratuur kom ondubbelsinnig na vore in die aanspreek van 'n seun deur sy vader of moeder: Hier is die 'seun'-formule 'my seun' (בניר) kenmerkend: 'My seun, luister na die tug van jou vader en moenie die onderwysing van jou moeder verwerp nie' (Spr 1:8). Die antieke Israelitiese wys- 
heidsleraars was waarskynlik geneig om hul leerlinge as 'seuns' aan te spreek. Hierdie onderrigsituasie was nie uniek in die Ou Nabye Ooste nie; dit vorm deel van ' $n$ internasionale instruksie-genre (vgl McKane 1970:6) soos duidelik blyk uit die epiloog van die lering van Ptahhotep (vgl Pritchard 1969:414) en in die Agikarspreuke waarin Agikar sy aangenome seun Nadin as 'my seun' aanspreek (vgl Pritchard 1969:429).

Die uitdrukking 'my seun' kom nie minder nie as twee en twintig keer in die Spreukeboek voor en in al die gevalle is die situasie onderrigtend (Spr 1:8, 10, 15; $2: 1 ; 3: 1,11,21 ; 4: 10,20 ; 5: 1,20 ; 6: 1,3,20 ; 7: 1 ; 19: 27 ; 23: 15,19,26 ; 24: 13,21$ en 27:11). In Prediker kom dit een keer voor (Pred 12:12) en dit ontbreek in Job. Naas die aanspreekvorm 'my seun' in Spreuke kom die aanspraak ook in die meervoud voor, soos 'luister, seuns' (Spr 4:1) asook 'en nou seuns, luister na my' (Spr 5:7; $7: 24$ en 8:32).

In die psalmbundel kom hierdie didaktiese situasie waarin seuns (kinders) aangespreek word, slegs een keer voor (vgl ook Ps 49:2; 78:1 vir 'n didaktiese situasie): 'Kom, kinders, luister na my, ek wil julle die vrees vir Jahwe leer' (Ps 34:12).

Dit blyk dus dat die onderrig gerig aan 'seuns' tiperend van die wysheid is en dus as wysheidskriteria gebruik kan word.

\subsubsection{Die retoriese vraag}

'n Retoriese vraag is 'n vraag waarop geen antwoord verwag word nie, aangesien die antwoord reeds veronderstel word uit die vraag se konteks: 'Het die reën 'n vader? Of wie verwek die doudruppels?' (Job 38:28). Die retoriese vraag is 'n nuttige didaktiese hulpmiddel aangesien dit insig by die leerling stimuleer (vgl Wolff 1964:7; Bauer-Kayatz 1969:15) en dit is daarom te verstane dat die wysheidsleraars dit gebruik. Hierdie vraagvorm is algemeen in die wysheidsboeke Job, Spreuke en Prediker - by laasgenoemde is die veronderstelde antwoord altyd negatief (Loader 1984:14) (vgl bv Job 38, 39 met sy talle retoriese vrae; Spr 5:16, 20; 6:9, 27, 28; $17: 16 ; 18: 14 ; 20: 9 ; 22: 27 ; 27: 24 ; 30: 4 ; 31: 10$, asook Pred $1: 3,10 ; 2: 15,19,25 ; 3: 9,21$, $22 ; 4: 11 ; 5: 5,10 ; 6: 12 ; 7: 24 ; 8: 7 ; 10: 14)$.

In die Psalms kom die retoriese vraag baie algemeen voor, soos byvoorbeeld in Psalm 2:1; 6:6; 8:5; 11:3; 18:32; 27:1; 30:10; 34:13; 42:6; 44:22; 49:6; 50:16-17, 21; 77:8-10, 14 en 94:9-10. Ook in die Profeteliteratuur is dit nie vreemd nie (vgl bv Esg 22:2, 14; Am 3:3-8; Miga 6:6-8).

Dat die wysheid 'n besondere liefde vir die gebruik van die retoriese vraag het, is duidelik maar dit is nie beperk tot die wysheid nie. Die retoriese vraag sal dus wel as wysheidskriterium gebruik kan word, maar net in samehang met ander wysheidskriteria. 


\subsubsection{Die vermaning}

Die vermaning is ' $n$ waarskuwende opdrag of advies en kom nie net in die wysheidsliteratuur voor nie: 'Moenie haastig wees in jou gees om jou te vererg nie, want woede rus in die boesem van die dwase' (Pred 7:9). Dit is vanweë sy teregwysende aard ook ewe goed tuis by die Deuteronomis en die profete (vgl Kuntz 1974:193). Die didaktiese karakter van die wysheidsliteratuur leen hom egter daartoe om ruimskoots van die vermaning gebruik te maak, omdat dit vir'n pedagogiese doel benut word. Dit wil voorkom of die wysheidsleraar die jussiewe vermaning met sy sagter en persoonliker appèl verkies bo die imperatiewe vermaning, om so die goeie gesindheid van sy leerlinge te wen. Om sy vermaning te onderbou, maak die wysheidsleraar soms gebruik van'n motiverende frase ingelei deur כי. Die vermaning kan negatief (אל gevolg deur die jussief) of positief geformuleer word (met die jussief of imperatief). Die vermaning kom algemeen in Spreuke en Prediker voor, maar is seldsaam in Job. In die psalmbundel is die vermaning ook nie vreemd nie, soos blyk uit Psalm 26:9-10; 32:9-11; 34:4, 10, 14; 37:1-2, 3, 5, 8; 49:17-18.

Omdat die wysheidsliteratuur 'n voorliefde vir die gebruik van die vermaning het, kan dit wel as wysheidskriterium gebruik word. Weer eens moet daarop gewys word dat die vermaning alleen nie van 'n stuk literatuur wysheid maak nie, aangesien die vermaning dwarsdeur die Ou Testament voorkom (vgl Richter 1966:67). Hierdie kriterium kan slegs in samehang met ander gebruik word om 'n psalm as wysheidsliteratuur te tipeer.

\subsubsection{Die vergelyking}

Die vergelyking kan nuttig in die onderwyssituasie gebruik word, aangesien die twee sake wat met mekaar vergelyk word 'n illustratiewe beeld oproep wat maklik deur die wysheidsleraar se leerlinge onthou kan word omdat dit uit hulle ervaringswêreld kom (vgl ook die'beter'-spreuk hierbo wat ook 'n tipe vergelyking is).

Die 'soos'-vergelyking kom in Job, Spreuke en Prediker voor (die vergelyking tussen mens en dier was blykbaar gewild by die wysheid): 'Soos 'n hond terugkeer na sy braaksel, herhaal 'n dwaas sy sotheid' (Spr 26:11).

Soms ontbreek die 'soos' in die vergelyking en word die twee vergelykende sake asindeties naas mekaar gestel. Die parallelismus membrorum wat algemeen in die Semitiese poësie gebruik word, maak dié soort vergelyking stilisties maklik moontlik. Hierdie tipe vergelyking kom veral algemeen voor in Spreuke 25-27 (vgl Von Rad 1970:159): 'n 'Vuil fontein en 'n besoedelde bron, 'n regverdige wat wankel voor 'n goddelose' (Spr 25:26).

Soos in die hele Ou Testament is die vergelyking in die psalms ook ' $n$ algemene verskynsel (vgl Ps $1: 3,4 ; 17: 12 ; 21: 10 ; 49: 13,21 ; 127: 4 ; 128: 3$ ). Dit is ook te 
verwagte dat die vergelyking nie die alleeneiendom van die wysheid kan wees nie omdat dit ' $n$ algemene verskynsel is. Nogtans maak die wysheid opvallend graag van die vergelyking gebruik. Die vergelyking kan dus as wysheidskriterium gebruik word - weer eens in samehang met ander wysheidskriteria. Kuntz (1974:199) wys daarop dat ' $n$ mens selfs dàn versigtig moet wees: Wanneer die vergelyking byvoorbeeld in 'n psalm saamhang met die vergeldingsleer kàn dit 'n aanduiding van 'n wysheidspsalm wees. Dit is egter nie noodwendig die geval nie, want die vergelding kom ook buite die wysheid voor.

\subsubsection{Wysheidwoordeskat}

Aangesien die wysheidsliteratuur veral op sekere motiewe konsentreer (vgl bv die inhoudelike kriteria) sou mens verwag dat daar telkens woorde gebruik sou word wat met hierdie sake saamhang. Dit gebeur ook dat sekere woorde meer algemeen

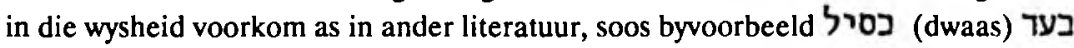
(dom wees), חכרשה (wysheid), חכס (whsig). Sulke woorde is egter nie beperk tot die wysheid nie, aangesien dit ook in ander literatuur voorkom. Daar kan verwag word dat 'n stuk literatuur wysheid sou wees, indien baie van hierdie woorde sáám daarin voorkom. 'n Mens sou egter baie versigtig moet wees in die gebruik van wysheidswoorde vir die uitwys van wysheidsliteratuur, omdat die wyse, profeet en priester 'n gemeenskaplike woordeskat gebruik het (Crenshaw 1969:133). Wat die boek Psalms betref, kan dit wel as 'n kriterium gebruik word, maar met 'n baie lae voorkeur: Aangesien die meeste psalms kort gediggies is, kry die digter nie noodwendig geleentheid om wysheidswoorde te gebruik nie - 'n geleentheid wat hom makliker in 'n langer literêre werk kan voordoen (vgl Whybray 1974:116). Die weglating van wysheidswoorde in 'n psalm sluit dus nie die moontlikheid uit dat dit ' $n$ wysheidspsalm kan wees nie. Aan die ander kant dui die voorkoms van wysheidswoorde in 'n psalm slegs op die moontlikheid dat dit ' $n$ wysheidspsalm kan wees - ander kriteria sal die deurslag moet gee (vgl Whybray 1974:142-149 vir die frekwensie van wysheidswoorde in die wysheidsliteratuur en ander boeke in die Ou Testament; asook Kuntz 1974:201).

\subsubsection{Die spreuk (vgl ook die 'beter'-spreuk en die getallespreuk hierbo)}

Die spreuk (משל) wat so kenmerkend van die wysheidsliteratuur is, is die mees fundamentele bousteen van die wysheid. Die spreuk word veral deur middel van die stylfiguur parallelismus membrorum uitgedruk, waardeur die digter sy onderwerp deur middel van twee parallelle stiges belig. Die twee stiges kan sinoniem, antiteties of sinteties wees. Dit beteken onderskeidelik dat dieselfde gedagte op verskillende wyses deur die twee stiges weergegee word, die twee stiges die 
teenoorgestelde idee weergee, en dat die aanvanklike gedagte in die res van die spreuk uitgebrei of voltooi word. Die volgende voorbeelde van onderskeidelik die sinonieme, antitetiese en sintetiese wysheidspreuke druk algemeen geldende lewenswaarhede uit en staan gevolglik as waarspreuke bekend: 'Yster is vir hom soos strooi, koper soos verrotte hout' (Job 41:19). 'n 'Genadige man doen goed aan homself, maar 'n wreedaard pynig sy eie vlees' (Spr 11:17). 'Twee is beter as een, want hulle het goeie beloning vir hulle moeite' (Pred 4:9).

Alhoewel Spreuke nie net in die wysheidsliteratuur voorkom nie (vgl 1 Sam $24: 14 ; 2$ Sam 5:8; 1 Kon 20:11; Jer 23:28; $31: 29$ ), is dit so eie aan die wysheid dat dit 'n goeie aanduiding van wysheidsliteratuur is.

\subsubsection{Inhoudelike kriteria}

\subsubsection{Die regverdige teenoor die goddelose en die vergeldingsleer}

Uit die voorkoms van die twee terme 'regverdige' (צריק) en 'goddelose' ( die Ou Testament is dit duidelik dat dié twee groepe baie belangrik in die wysheidsliteratuur en die psalms is. Die volgende tabel toon hoeveel keer dit in die wysheidsliteratuur en psalms in verhouding tot die res van die Ou Testament voorkom:

Job Spreuke Prediker Psalms Die res van die Ou

Testament

\begin{tabular}{llllll}
\hline Pיצ & 7 & 66 & 8 & 52 & 73 \\
רעי & 26 & 78 & 7 & 82 & 70 \\
\hline
\end{tabular}

In die wysheidsliteratuur word die regverdige en die goddelose teenoor mekaar gestel. Hulle verteenwoordig twee kontrasterende groepe mense wat nooit met mekaar versoen kan word nie. Hulle lewenswyses staan lynreg teenoor mekaar: Die regverdige verlustig hom in Jahwe se wet (Ps 1:2; 37:31), is vrygewig teenoor sy medemens (Ps 37:21), dit gaan vir hom nie oor rykdom nie (Ps 37:16), nogtans ken hy vreugde (Spr 10:28) en voorspoed (Spr 10:30), aangesien Jahwe hom ondersteun (Ps 37:17). Alhoewel die regverdige nie immuun teen die goddelose se aanslae is nie (Ps 37:12, 14; Spr 24:15), help Jahwe hom (Ps 37:32). Die uiteinde van die regverdiges is dat hulle erfdeel vir ewig sal stand hou (vgl Ps 37:18, 29; Spr 10:15). Die goddeloses, daarenteen, ontferm hulle nie teenoor andere nie (Ps 37:12) - hulle 
leen eerder sonder om terug te gee (Ps 37:21); hulle is vals ( $\mathrm{Spr}$ 10:32), wreed (Spr 12:10) en bedink listige planne teen die regverdiges (Ps 37:12). Jahwe vervloek

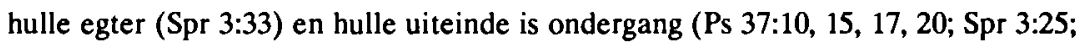
$10: 7,25)$.

Uit die tabel hierbo is dit duidelik dat die regverdige en die goddelose nie net dikwels in die wysheidsliteratuur voorkom nie, maar ook in die psalmbundel ( $\mathrm{vgl} \mathrm{bv}$ Ps 32:10; 36:2, 12; 37:28, 34, 38; 73:3, 12; 75:5; 94:21; 97:11, 12; 112:4). Hoewel dit interessant is, skep dit ook 'n probleem vir die doel van hierdie studie wat juis die wysheidspsalms wil identifiseer - al die psalms waarin die twee terme voorkom, kan nie wysheidspsalms wees nie (vgl ook die bespreking van wysheidswoordeskat hierbo). Ander wysheidskriteria sal moet bykom as argument vir die kategorisering van 'n psalm as wysheidspsalm. ' $n$ Inhoudelike aspek wat juis hier in kombinasie met die kontras tussen die regverdige en die goddelose na vore dring, is die vergelding. Alhoewel die vergelding ook buite die wysheid voorkom - dit kom trouens redelik algemeen in die Ou Testament voor - reflekteer die wysheid meer spesifiek daaroor. Die vergelding en die kontras tussen die regverdige en die goddelose kom soms in die wysheid sáám in dieselfde spreuk voor. Wanneer dit ook in die psalmbundel plaasvind, bied dit 'n dubbele argument ten gunste daarvan dat die betrokke psalm 'n wysheidspsalm is.

In die wysheidsliteratuur kan die kontras tussen die regverdige en die goddelose in samehang met die vergelding voorkom: 'Die vloek van Jahwe is op die huis van die goddelose, maar Hy seën die woning van die regverdiges' (Spr 3:33 - vgl met Spr 10:3).

Jahwe sorg dus vir die vergelding - Hy sorg dat dit goed gaan met die regverdige en sleg met die goddelose. Ook in Prediker kom hierdie twee aspekte saam voor, hoewel Prediker rebelleer teen die gedogmatiseerde vergelding, soos dit oor die algemeen in Spreuke voorkom. Dit blyk uit die volgende dat Prediker, wanneer hy na die regverdige en die goddelose kyk, meen dat die vergelding glad nie bestaan nie: 'Dit is 'n nietigheid wat op die aarde gebeur: Daar is regverdiges met wie dit gaan na die verdienste van die goddeloses en daar is goddeloses met wie dit gaan na die verdienste van die regverdiges' (Pred 8:14). Ook in die psalms kom die twee aspekte saam voor wat dan die skaal laat swaai in die rigting van 'n wysheidspsalm: 'Onheil sal die goddelose doodmaak en die haters van die regverdige sal skuldig wees' (Ps 34:22, vgl Ps 37:17).

Hoewel die kontras tussen die regverdiges en die goddeloses asook die vergelding nie eksklusief in die wysheid voorkom nie (vgl ook Jes 3:10-11; Eseg 3:17. 21), is dit algemener in die wysheid as in die res van die Ou Testament. Omdat dit ook dikwels in die psalmbundel voorkom, kan die twee aspekte nie alleén as 
wysheids-kriteria dien nie, maar wel in samehang met ander kriteria.

\subsubsection{Die twee weẽ}

In noue verband met die kontras tussen die regverdige en die goddelose staan die sogenaamde twee weě: 'Om jou te red van die slegte weg, van die mens wat valshede spreek; wat reguit paaie verlaat om op die weë van duisternis te wandel' (Spr $2: 12,13)$. Net soos daar nie 'n tussenposisie tussen die regverdige en die goddelose kan wees nie, so kan daar ook nie meer as twee weë wees nie. Daar is naamlik slegs die regte weg (die weg van die regverdige) en die verkeerde weg (die weg van die goddelose). Die vergelding moet hiermee saam gesien word, want Jahwe vergeld die mens ooreenkomstig sy optrede: die 'weg' wat hy bewandel.

Omdat die twee weê deel uitmaak van die gedagtekompleks: die vergelding van die regverdige en die goddelose, en omdat dit ook algemeen in die Spreukeboek voorkom, kan dit as kriterium vir die identifisering van wysheidspsalms dien.

\subsubsection{Die vrees vir Jahwe en die wet van Jahwe (die Tora)}

Hierdie twee inhoudelike aspekte word soms in die Ou Testament parallel teenoor mekaar gestel, waaruit afgelei kan word dat Jahwe gevrees word deur sy wet na te kom (vgl bv Deut 31:12; Ps 112:1; Spr 2:1, 5).

Die hoë voorkoms van die uitdrukking 'vrees vir Jahwe' toon aan dat dit 'n tipiese wysheidsuitdrukking is: van die twee en twintig keer dat dit in die hele Ou Testament voorkom, kom dit vyftien keer in die wysheid, naamlik die Spreukeboek, voor (Spr 1:7, 29; 2:5; 8:13; 9:10; 10:27; 14:26, 27; 16:16, 33; 16:6; 19:23; 22:4; 23:17; 31:30). Op grond hiervan kan die uitdrukking as wysheidskriterium gebruik word. Tog kan die voorkoms van die uitdrukking alléén nie van 'n psalm 'n wysheidspsalm maak nie - die psalm sal ook ander wysheidskriteria moet vertoon.

Die term wet (תררה) kom uit die tweehonderd en twintig keer wat dit in die Ou Testament voorkom, slegs twaalf keer in Spreuke voor en een keer in Job terwyl dit in Prediker ontbreek (Spr 1:8; 3:1; 4:2; 6:20, 23; 7:2; 13:14; 28:4, 7, 9; 29:18; 31:26; Job 22:22). In die psalms kom dit drie en dertig keer voor. Die term nררה kan as 'wet' vertaal word of as gevolg van die didaktiese konteks wrarin dit soms voorkom, kan dit ook as onderwysing vertaal word. Alhoewel dié term verreweg meer buite die wysheid as daarbinne voorkom, neem dit 'n belangrike plek in die wysheid in en kan dit saam met ander kriteria wel as wysheidskriterium gebruik word. 


\subsubsection{Praktiese raad in verband met die alledaagse lewe}

Die wysheid bevat raad oor alledaagse gedrag, want dit is bedoel om die wyse mens te help met sy gedrag in die gewone lewe. Die wyse moet op 'n sekere manier leef, want hy moet by die orde van Jahwe se skepping inpas. Hy moet byvoorbeeld oppas vir die verleiding deur die sondaars (Spr 1:10), oppas vir die slegte geselskap (Spr $1: 10,2: 12$ ), en die slegte vrou (Spr 6:24-25). Hy moet hardwerkend (Spr 10:5) en barmhartig wees (Spr 11:17) en die goeie doen (Spr 2:20). Aangesien hierdie praktiese raad so kenmerkend van die wysheld is, kan dit, hoewel nie net op sy eie nie, as wysheidskriterium gebruik word.

\subsection{Die wysheidskriteria}

Uit die evaluering blyk dat die volgende inhoudelike en formele aspekte wysheidskriteria is waarvolgens die wysheidspsalms uitgeken kan word. Al hierdie aspekte hoef nie in dieselfde psalm voor te kom nie, maar die voorkoms van 'n aantal formele en inhoudelike kriteria in een psalm, versterk die argument dat dit 'n wysheidspsalm is. Die beginsel vir die bepaling van die wysheidspsalms is dus ' $n$ samevloei van getuienis: meerdere inhoudelike en formele kenmerke moet in kombinasie voorkom alvorens 'n bepaalde psalm as wysheidspsalm kan geld.

\section{Formele kriteria}

Die 'seën'-formule; die 'beter'-spreuk; die alfabetiese struktuur; die getallespreuk; die 'seun'-formule; die retoriese vraag; die vermaning; die vergelyking; wysheidswoordeskat; die spreuk.

\section{Inhoudelike kriteria}

Die regverdige teenoor die goddelose; die vergeldingsleer; die twee weë; die vrees vir Jahwe; eerbied vir die Tora; praktiese raad in verband met die alledaagse lewe.

Inhoudelike en formele kenmerke moet saam in 'n psalm voorkom om die betrokke psalm as wysheidspsalm te tipeer. Formele wysheidskenmerke alleen maak nog nie van 'n psalm 'n wysheidspsalm nie - dit gaan tog uiteraard om die inhoud van die psalms. So het Psalm 78 'n didaktiese inleiding wat formeel kenmerkend van die wysheid is ('My volk, luister na my onderrig'). Die res van die psalm handel egter oor historiese verwysings wat inhoudelik niks met wysheid te doen het nie. Hierdie psalm is beslis nie 'n wysheidspsalm nie. 'n Mens sou kon sê dat indien die inhoud van 'n bepaalde psalm kenmerkend van die wysheid is maar die formele wysheidskenmerke ontbreek, dit meer geredelik as 'n wysheidspsalm geklassifiseer kan word. Dit gaan immers in die eerste instansie om inhoud: Voorbeelde hiervan ontbreek egter in die psalmbundel - miskien omdat bepaalde formele verskynsels ken- 
merkend van poësie is - en is gevolglik nie 'n probleem nie.

Ons het nou die kriteria vasgestel met behulp waarvan wysheidspsalms uitgeken kan word. By die oorweging hiervan het dit reeds geblyk dat die kriteria nie na willekeur gebruik kan word nie, maar dat daar 'n bepaalde dissipline in hul toepassing moet geld. Dit bring ons by 'n punt waar 'n norm geformuleer kan word.

Psalms wat meerdere kenmerke uit beide die formele en die inhoudelike kategorieë vertoon, is wysheidspsalms. Drie beperkinge moet dus op die aanwending van die kriteria geplaas word: Daar moet formele kenmerke voorkom; daar moet inhoudelike kenmerke voorkom en daar moet verskeie van elk voorkom. Die psalms wat volgens hierdie kriteria as wysheidspsalms kwalifiseer, is Psalm 1, 32, 34, 37, 49 , 112,127 en 128.

\section{Literatuurverwysings}

Albright, W F 1950. Some important recent discoveries: Alphabetic origins and the Idrimi statue. BASOR 118, 11-20.

Bauer-Kayatz, C 1969. Einflihrung in die alttestamentliche Weisheit. NeukirchenVluyn: Neukirchener Verlag.

Brockelmann, C 1966 [1913]. Grundriss der vergleichenden Grammatik der semitischen Sprachen, Band 2. Nachdruck. Hildesheim: Olms.

Crenshaw, J L 1967. The influence of the wise upon Amos: The 'doxologies of Amos' and Job 5:9-16, 9:5-10. ZAW 79, 42-52.

--- 1969. Method in determining wisdom influence upon 'historical' literature. $J B L$ 88, $129-142$.

--- 1981. Old Testament wisdom: An introduction. Atlanta: Knox.

Gordon, C H 1965. Ugaritic textbook. Rome: Pontifical Biblical Institute.

Gunkel, H 1975 [1933]. Einleitung in die Psalmen: Die Gattungen der religiösen Lyrik Israels. Zu ende geführt von Begrich, J. Göttingen: Vandenhoeck.

Kuntz, J K 1974. The canonical wisdom psalms of ancient Israel: Their rhetorical, thematic and formal dimensions, in Jackson, $\mathbf{J} \mathbf{J}$ \& Kessler, M (eds), Rhetorical criticism: Essays in honor of James Muilenburg, 186-222. Pittsburg: Pickwick.

--- 1977. The retribution motif in psalmic wisdom. $Z A W$ 89, 223-233.

Loader, J A 1984. Prediker: Een praktische bijbelverkalring. Kampen: Kok. (TT.)

-- 1985. Jedidiah or: Amadeus. Thoughts on the succession narrative and wisdom. Lesing gelewer tydens die OTWSA-kongres, Pretoria.

McKane, W 1970. Proverbs: A new approach. London: SCM. (OTL.)

Mowinckel, S 1950-1951. Tradisionalism and personality in the psalms. HUCA 23/1, 205-231. 
--- 1960. Psalms and wisdom, in Noth, M \& Thomas, D W (eds), Wisdom in Israel and the Ancient Near East, 175-187. Leiden: Brill.

-. 1962. The psalms in Israel's worship, vol 2. Translated by Ap-Thomas, D R. Oxford: Blackwell.

Murphy, R E 1962. A consideration of the classification 'wisdom psalms'. SVT 9, 156-167.

Pritchard, J B (ed) 1969. Ancient Near Eastem texts: Relating to the Old Testament. Princeton: Princeton University Press.

Richter, W 1966. Recht und Ethos: Versuch einer Ortung des weisheitlichen Mahnspruches. München: Kösel.

Schmid, H H 1966. Wesen und Geschichte der Weisheit: Eine Untersuchung zur altorientalischen und israelitischen Weisheitsliteratur. Berlin: Töpelmann. (BZAW.)

Scott, R B Y 1971. The way of wisdom in the Old Testament. New York: Macmillan.

Von Rad, G 1970. Weisheit in Israel. Neukirchen-Vluyn: Neukirchener Verlag.

Whybray, R N 1974. The intellectual tradition in the Old Testament. Berlin: De Gruyter. (BZAW.)

Wolff, H W 1964. Amos' geistige Heimat. Neukirchen-Vluyn: Neukirchener Verlag. 